\title{
Production of bio-electricity during wastewater treatment using a single chamber microbial fuel cell
}

\author{
B.K. Pandey ${ }^{1}$, V. Mishra ${ }^{2}$, S. Agrawal $^{3}$ \\ ${ }^{1}$ Department of Applied Sciences, Madan Mohan Malaviya Engineering College,Gorakhpur, INDIA \\ ${ }^{2}$ Department of Electrical Engineering, Madan Mohan Malaviya Engineering College,Gorakhpur, INDIA \\ ${ }^{3}$ Department of Electrical Engineering, Madan Mohan Malaviya Engineering College,Gorakhpur, INDIA \\ Corresponding Author: B. K. Pandey, Email-bkp11@rediffmail.com, Fax No.0551-2273958, Mob. No. 09415244487
}

\begin{abstract}
Microbial fuel cells (MFCs) represent a completely new long term, affordable, accessible and ecofriendly approach to waste water treatment with production of sustainable energy. The power generation efficiency in microbial fuel cells (MFCs) is based on bioreactors, which may represent a completely new approach to wastewater treatment. In our experimental test we found that it is possible to generate electricity using bacteria while accomplishing waste water treatment in process based on microbial fuel cell technologies. Tests were conducted using a single chamber microbial fuel cell (SCMFC) containing eight graphite electrodes (anodes) and a single cathode. The prototype SCMFC generated electrical power (maximum1 $8 \mathrm{mWm}^{-2}$ ). Power generation in these systems can be increased by using suitable electrodes with the choice of appropriate bioreactor and fuel.
\end{abstract}

Keywords: Microbial fuel cells,microbial communities, bio electricity generation ,proton-exchange membrane, electricitygeneration, power-generation, bacterial communities, anaerobic-oxidation.

\section{Introduction}

Microbial fuel cells are devices that directly convert chemical energy to electricity through catalytic activities of microorganisms (Kim et al ,1999a,1999b) (Logan et al ,2006) (Chaudhari et al,2003) (Logan et al,2006c).Electricity has been generated in MFCs form various organic compounds including Carbohydrates, proteins and fatty acids (Kim et al ,1999a,1999b). One of the greatest advantages of MFCs over conventional fuel cells like hydrogen and methanol fuel cell is that a diverse range of Organic material can be used as fuels. A microbial fuel cell (MFC) is a device that converts chemical energy to electrical energy with the aid of microorganisms (Logan et al, 2006) (Chaudhari et al, 2003) (Logan et al, 2009).A MFC consists of anode and cathode separated by a cation specific membrane. Microbes in the anode oxidize fuel here bacteria gain energy for metabolism by transferring electrons from an electron donor, such as glucose or acetate to an electron acceptor such as oxygen and the resulting electrons and protons are transferred to cathode through the circuit and the membrane respectively. Electrons and protons are consumed in the cathode, reducing oxidant usually oxygen. Since the microbial cells are electrochemically inactive due to nonconductive cell surfaces structure, mediators are employed to facilitate electron transfer from the microbial cells to the anode in MFCs (Cheng et al, 2006; Kim et al, 2009; Kim et al, 2010).

1.1Microbial fuel cell system: MFCs are being constructed using a variety of materials and in an ever increasing diversity of configurations. These systems are operated under a range of conditions that include differences in temperature, $\mathrm{pH}$, electron acceptor, electrode surface areas, reactor size and operation time. It was only recently discovered that the respiratory enzymes of certain iron reducing bacteria span their outer membrane allowing a direct transfer of electrons to the external metals such as $\mathrm{Fe}(\mathrm{III})$ or $\mathrm{Mn}(\mathrm{IV})$. The attachment of these bacteria to carbon electrodes results in electron transfer to the anode, with oxygen reduction at cathode .Power generated in various types of MFCs operated using mixed cultures currently achieve substantially greater power densities than those with pure cultures (Logan et al, 2006; Chaudhari et al, 2003; Gil et al, 2003) (Kim et al ,2010). 
MFC systems vary widely as a function of the inoculums, substrate, and reactor, ranging from $<1 \mathrm{~mW} / \mathrm{m}^{2}$ with lactate and pure culture to $3600 \mathrm{~mW} / \mathrm{m}^{2}$ with glucose and mixed cultures of microbes (Gil et al, 2003). However most results with carbon electrodes generally report power generation rates of $10-100 \mathrm{~mW} / \mathrm{m}^{2}$.

Table 1. Maximum power densities in various MFCS using mixed culture reported by different group of scientists.

\begin{tabular}{|c|c|c|c|}
\hline Reactor type & Fuel used & $\begin{array}{ll}\text { Power } & \text { Density } \\
\left(\mathrm{mW} / \mathrm{m}^{2}\right) & \end{array}$ & Reference \\
\hline Single chamber & Glucose & 766 & Cheng et al 2006a \\
\hline Single chamber & $\begin{array}{l}\text { Domestic } \\
\text { wastewater }\end{array}$ & 464 & Cheng et al 2006a \\
\hline Two chamber & Glucose & 860 & Liu et al 2005 \\
\hline Two chamber & Acetate & 480 & Cheng et al 2006b \\
\hline Up flow & Sucrose & 560 & Bond and Lovely 2003 \\
\hline
\end{tabular}

Table 2. Maximum power densities in various MFCS, using pure culture reported by different group of scientists.

\begin{tabular}{|l|l|l|l|l|}
\hline Strain & Reactor type & Fuel used & $\begin{array}{l}\text { Power density } \\
\mathbf{( m W / \mathbf { m } ^ { 2 } )}\end{array}$ & Reference \\
\hline Escherichia Coli & Single chamber & $\begin{array}{l}\text { Complex } \\
\text { substrate }\end{array}$ & 600 & Zhang et al .2006 \\
\hline Shwenella Putrefaciens & Single chamber & Glucose & 355.5 & Bond and Lovely .2003 \\
\hline Geobacter sulfurreducens & $\begin{array}{l}\text { Double chamber } \\
\text { H-type }\end{array}$ & acetate & 13 & $\begin{array}{l}\text { Chaudhuri and Lovely } \\
\text { Bond and Lovely,2003 }\end{array}$ \\
\hline Shwenella Putrefaciens & $\begin{array}{l}\text { Double chamber } \\
\text { H-type }\end{array}$ & glucose & 33.4 & Bond and \\
\hline
\end{tabular}

\subsection{MFC Designs}

1.2.1 Two -Chambered MFC: The simplest type of MFC consists of two chambers separated by material that conducts protons between the chambers. This widely used and inexpensive design consists of two chambered MFC built in a traditional " $\mathrm{H}$ " shape, consisting of usually two bottles connected by a tube containing a separator which is usually a cation exchange membrane (CEM) such as Nafion or Ultrex or a simple salt bridge. The key to this design is the choice of a membrane that allows protons to pass between chambers (CEM is also called a proton exchange membrane, PEM) but optimally not the substrate or electron acceptor in cathode chamber typically oxygen. The electrodes can be made of any conducting, non-corrosive, depending on the system plain carbon paper, carbon cloth, or graphite is used for the anode. The cathode must contain a catalyst for generating water from the protons, electrons and oxygen and typically $\mathrm{Pt}$ is used and held on carbon surface using a binder. The electrodes are connected by copper wire with all surfaces coated with a non-conductive epoxy. To avoid wires inside the chambers the carbon electrodes are extended outside the chamber and then a regular wire and clip can be used on electrode. The anode chamber contains the biodegradable substrate and nutrients (nitrogen, phosphorous, oxygen and trace mineral). The oxygen should not diffuse into the anode chamber and it is found that the rate of oxygen diffusion into the anode without a PEM is $2.7 \%$ higher than a double chamber design using a Nafion membrane (Logan et al, 2006; Kim et al, 2010).

1.2.2 Single chamber MFC: A simpler and more efficient MFC can be made by omitting the cathode chamber and placing the cathode electrode directly onto the PEM.This setup avoids the need to aerate water because the oxygen in air can be directly transferred to the cathode. Several designs are possible for this system, in the first design used in laboratories which is used to demonstrate electricity generation from wastewater ,the cathode was placed in the center of a cylinder so that anode chamber formed a concentric cylinder around the cathode (large SCMFC) (Cheng et al,2006a). Graphite rods were placed inside the anode chamber and these rods extended outside of the anode chamber and were connected to the cathode via an external circuit. Air is made to bubble through the center tube so that it can react at the cathode. The Nafion membrane was hot -pressed onto the cathode which was wrapped around a perforated plastic tube to provide support, with the membrane in contact with the solution at anode chamber.

In another type of SCMFC there is a single tube with the two circular electrodes placed on opposite ends of the tube (small SCMFC) (Cheng et al, 2006a). The end containing the anode is wrapped in order to prevent oxygen diffusion into the chamber, while the other end is open so that one side of the cathode faces air, while the other is bounded to the PEM and faces the solution in the chamber. 


\section{Experimental setup}

2.1 Materials and Operation: We designed a single chambered MFC (SCMFC) in our laboratory which consists of a single cylindrical plexiglass chamber $15 \mathrm{~cm}$ long by $6.5 \mathrm{~cm}$ diameter having volume of $388 \mathrm{~mL}$ containing eight graphite rods as anode each $6.15 \mathrm{~mm}$ in diameter and $150 \mathrm{~mm}$ long placed in a concentric arrangement about a single cathode. The graphite rod was abrased by sand paper to enhance bacterial attachment .The cathode consisted graphite rod although air cathodes having perforations for air flow can also be used. The protons exchange membrane Nafion (grade 117) the PEM was boiled sequentially in $\mathrm{H}_{2} \mathrm{O}_{2} \quad 30 \%$ and deionized water and $0.5 \mathrm{M} \mathrm{H}_{2} \mathrm{SO}_{4}$. The cathode was placed into a $7 \mathrm{~mm}$ diameter plastic tube containing $2 \mathrm{~mm}$ diameter pores at $2 \mathrm{~mm}$ distance. Air flow through the cathode was ensured by a common aquarium air pump.

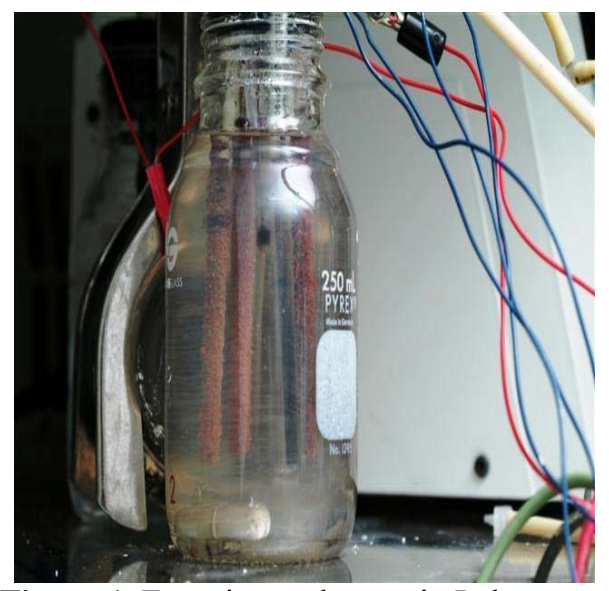

Figure 1. Experimental setup in Laboratory

2.2. Working: In normal microbial catabolism, a substrate such as a carbohydrate is initially oxidized anaerobically, when its electrons are released by enzymatic reactions.The electrons are stored as intermediates (e.g., Nicotinamide adenine dinucleotide $\mathrm{NADH}$, quinines) which become reduced and are then used to provide the living cell with energy. The ending location for the electrons is molecular oxygen or dioxygen at the end of the respiratory chain .A MFC uses bacteria to catalyze the conversion of organic matter into electricity by transferring electrons to a developed circuit. Microorganism can transfer electrons to the anode electrode in three ways first using exogenous mediators (ones external to the cell)such as potassium ferricyanide, thionine, or neutral red secondly using mediators produced by the bacteria and lastly by direct transfer of electrons from the respiratory enzymes(i.e. cytochrome) to the electrodes. These mediators can divert electrons from the respiratory chain to outer cell membrane, becoming reduced and then leaving in a reduced state to shuttle the electron to the electrode.(Logan et al ,2006; Cheng et al,2006a; Berk et al, 1964).

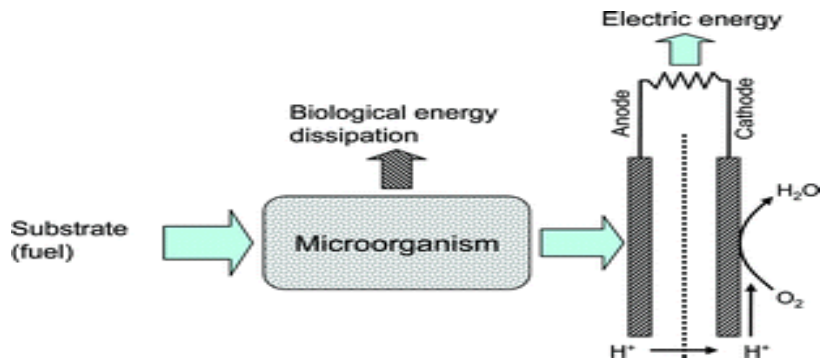

Figure 2 . Schematic working of a microbial fuel cell

2.3. Enzymatic Reactions: The basic reactions are presented below; when microorganisms consume a substrate such as sugar in aerobic condition they produce $\mathrm{CO}_{2}$ and $\mathrm{H}_{2} \mathrm{O}$. However when oxygen is not present i.e. under anaerobic condition they produce $\mathrm{CO}_{2}, \mathrm{H}^{+}$and $\mathrm{e}^{-}$.

Anodic reactions:

$\mathrm{C}_{12} \mathrm{H}_{22} \mathrm{O}_{11}+13 \mathrm{H}_{2} \mathrm{O} \rightarrow 12 \mathrm{CO}_{2}+48 \mathrm{H}^{+}+48 \mathrm{e}^{-}$

Cathodic reaction:

$\mathrm{O}_{2}+4 \mathrm{e}^{-}+4 \mathrm{H}^{+} \rightarrow 2 \mathrm{H}_{2} \mathrm{O}$ 
In various studies it has been found that pure cultures are not needed and that by using bacteria present in ordinary wastewater we could achieve power levels dependent on reactor configurations and operation (Logan et al ,2006)(Lovely et al ,2005) )(Kim et al ,2009)(Kim et al ,2010).

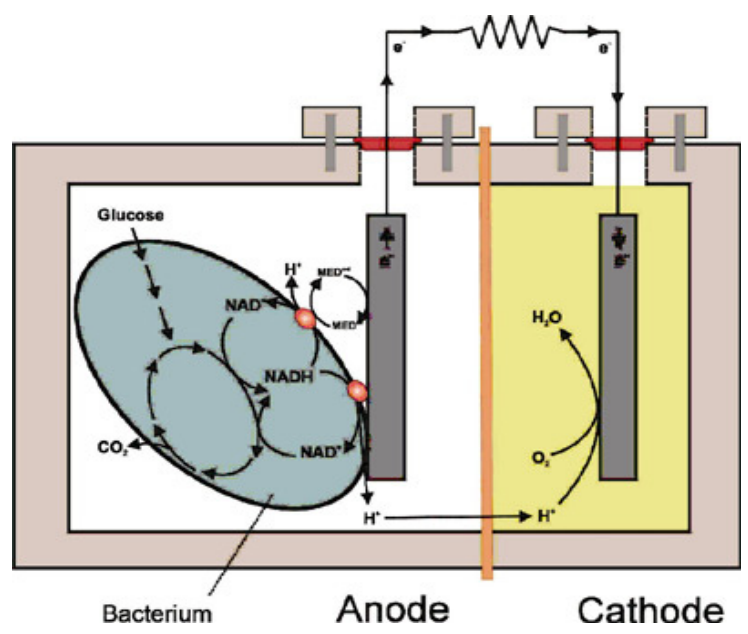

Figure 3. Representation of internal Enzymatic processes

\section{Instrument and Procedures for Reporting data:}

3.1 Instruments: In addition to the conventional instruments used for chemical measurements in microbial fuel cells(e.g. for determining the concentration and $\mathrm{pH}$,weights for chemicals) MFC experiment requires special electrochemical instrumentation .In most cases, cell voltages and electrode potentials are measured with commonly available voltmeters ,multimeters.Cell voltages can be determined directly from the voltage difference between the anode and cathode ,current is calculated using ohm's law $\left(\mathrm{I}=\mathrm{E}_{\text {cell }} / \mathrm{R}\right)$ using measured voltage.

3.2 Power: The overall performance of an MFC is evaluated in many ways, but principally through power output and coulombic efficiency. Power is calculated as

$$
\mathrm{P}=\mathrm{I} \mathrm{E}_{\text {cell }}=(\text { Ecell })^{2} / \mathrm{R}_{\text {cell }}
$$

3.3 Power Density: Power is often normalized of an MFC in order to make it possible to compare power output of different systems. The power output is usually normalized to the anode surface area because the anode is where the biological reactions occur therefore the power density $\left(\mathrm{P}_{\mathrm{AN}}, \mathrm{Wm}^{-2}\right)$ is calculated on the basis of the area of anode $\left(\mathrm{A}_{\mathrm{AN}}\right)$ as

$$
\mathrm{P}_{\mathrm{AN}}==(\text { Ecell })^{2} /\left(\mathrm{R}_{\text {cell }} \mathrm{A}_{\mathrm{AN}}\right)
$$

To perform engineering calculations the power is normalized to the reactor volume.

$$
\mathrm{Pv}==(\text { Ecell })^{2} /\left(\mathrm{R}_{\text {cell }} \mathrm{V}\right)
$$

3.4 Ohmic Losses: The ohmic losses in an MFC include both the resistance to the flow of electrons through the electrodes and interconnections, and the resistance to the flow of ions through the PEM and the Cathodic electrolytes .Ohmic losses can be reduced by minimizing the electrode spacing using a membrane with low resistivity, checking thoroughly the interconnections and contacts and increasing the solution conductivity by diluting the substrate with deionized water.

\section{Results and Discussions}

Electricity in the SCMFC was generated using domestic wastewater. The voltage across the circuit containing a $465 \mathrm{ohm}$ resistor increased to $0.32 \mathrm{~V}$ producing up to $173 \mathrm{mWm}^{-2}$ of power based on the anode surface area $\left(\mathrm{A}_{\mathrm{AN}}\right)$. Power output was a function of circuit load (16-5000 ohm)in the system, consistent with trends observed by others in other MFC experiments )(Kim et al, 2009)(Kim et al ,2010). At a hydraulic detention time of $95 \mathrm{~h}$, power reached a maximum of $26 \mathrm{~mW} / \mathrm{m}^{2}$, with a current density 
of $125 \mathrm{~mA} / \mathrm{m}^{2}$ in the absence of forced air flow through the cathode tube. In contrast, a maximum of only $12.2 \mathrm{~mW} / \mathrm{m}^{2}$ was achieved in the system with stopped air flow at a longer detention time (HRT ) greater than $95 \mathrm{~h}$. Electricity was immediately generated from glucose $(600 \mathrm{mg} / \mathrm{L} ; 1000 \mathrm{ohms})$ using the MFCs inoculated with bacteria in wastewater. In the carbon(graphite) electrode MFC containing a PEM (CE-PEM), a maximum of $0.32 \mathrm{~V}\left(173 \mathrm{~mW} / \mathrm{m}^{2}\right)$ was obtained, with the power slowly dropping to $0.25 \mathrm{~V}$ over the next $95 \mathrm{~h}$, and then sharply decreasing over the next $5 \mathrm{~h}$. In the MFC without a PEM(CE), a maximum of $0.52 \mathrm{~V}$ $(381 \mathrm{~mW} / \mathrm{m} 2)$ was generated with the voltage rapidly decreasing to low levels $(<0.044 \mathrm{~V})$ within $20 \mathrm{~h}$. Voltage output appeared to follow saturation kinetics as a function of glucose concentration. It was also observed that at lower external resistance the current production is higher and vice versa. For same waste water COD concentration the current production decreases with increase in resistance. These observations show that the resistance becomes the rate limiting steps. Even at lower resistance, low current production could be to the lower electron consumption rate at the cathode and the transfer rate from the external circuit. This might be due to limiting supply of proton or oxygen. The lower current production indicates some electrons are consumed by mechanism(s) other than expected cathode reaction. It is plausible that under the conditions of limiting electron disposal through the circuit with a high resistance, the electrons are consumed in the anode to reduce other electron acceptors such as Sulphate and Nitrate (Kim et al ,2010) or oxygen diffused from cathode compartment or dissolved oxygen present in the influent, or methane production in the anode compartment. Higher fuel oxidation by the microbes is expected at a low external resistance to remove organic contaminants at a high rate (Jang et al., 2004).

Although the changes in Biochemical Oxygen Demand (BOD) and Chemical Oxygen Demand (COD) were not measured in experiment, the changes in the amount of BOD removed and COD removed would give the data about the concentration and biodegradability of organic matter fed into the MFC (Logan et al,2006; Ramnarayan et al ,2004). BOD and COD removal were the function of detention time of waste water in the chambers (Kim et al, 2010). While full- scale, highly effective MFCs are not yet economically feasible this technology holds considerable promise and major hurdles will be undoubtedly overcome by scientists and engineers. The going pressure on our environment and the need for long term renewable energy sources will further speed up development of Microbial fuel cells.

\section{Applications and Outlook}

The major applications will development of cells at industrial locations were high concentration organic substrate is available .In another area the domestic sewage could be treated with MFCs decreasing societies need to invest substantial amount of power in their treatment. These can be very useful in space waste regeneration and in developing bio-sensors. MFC designs need improvement before a marketable product will be possible .Most of the designs cannot be scaled to the level needed for the large scale waste water treatment plant which requires hundreds of cubic meters of volume and large amount of substrates. The success of MFC applications in wastewater treatment will depend upon the concentration and biodegradability of organic matter in substrate the temperature .Materials cost will be large factor in total MFC cost.

\section{Acknowledgments}

This research was supported by Department of Electrical Engineering and Department of Applied Sciences at Madan Mohan Malaviya Engineering college Gorakhpur, U.P India .We thanks Prof. J.P Saini Principal of our college and Prof. K.G.Upadhyay Dean and Head Department of Electrical Engineering, for their guidance and providing necessary laboratory facilities.

\section{References}

Berk R. S., Canfield J. H. ,1964. Bioelectrochemical energy conversion, Nature Biotechnology).

Bond, Lovely D. R. ,2005.Electricity production by iron degrading microbes in MFC, Nature Biotechnology, pp. 163-177.

Byung H. K., Chang S, Gadd M., 1999a,1999b.Challenges in Microbial fuel cell Development and operation.

Chaudhari S. K., Lovely D. R., 2003. "Electricity generation by direct oxidation of glucose in microbial fuel cells", Nature Biotechnology, pp. 111-114.

Chaudhari S. K., Lovely D. R., Logan B. E., 2006. Continuous current generation using MFC type biosensors, pp. 86-88.

Cheng S., Liu H., Logan B.E., 2006a. Increased performance of single chambered MFCs using an improved cathode structure, Electro. Chem. Biocommunity, pp. 888-891.

Cheng S., Liu H., Logan B.E., 2006b. Power generation in a continuous flow MFC with porous electrodes and reduced electrode spacing, Environ. Sci. Biotechnology, pp. 110-114.

Cohen B., Rao J. R., 2002.The bacterial culture as an electrical half cell, Environ. Sci Biotechnology.

Ghangrekar M. M., Shinde V. B., 2006. Continuous electricity generation at high voltages and currents using stacked MFCs, Environ. Sci. Technol. Vol 40, pp 116-119.

Ghangrekar M. M., Shinde V. B., 2007. Performance of microbial fuel cells treating wastewater and effect of electrode distance and area of electrodes, Nature Biotechnology, pp. 63-67. 
Gil G. C. et al., 2003. Operational parameter affecting the performance of a mediatorless microbial fuel cell, Biosens. Bioelectron, vol 18, pp. 327-334.

Jang J. K. et. al.2004. Construction and operation of a novel mediator- and membrane-less microbial cell, Process Biochem.vol 39, pp. 1007-1012.

Kim J.R., 2009. Application of bio-electrochemical process (BES) for electricity generation and sustainable wastewater treatment,EKC.

Kim J.R., Premier, Lee G.C., 2010. Sustainable wastewater treatment : how might microbial fuel cells contribute ,Biotechnol advances vol.286, pp. 871-881 .

Logan B.E, Rabaey K, 2006. Microbial fuel cells methodology and technology, pp. 11-17.

Logan B.E,Rabaey K. ,2005.Continuous Electricity generation from domestic wastewater and organic substrates using a Flat plate Microbial fuel cell .

Logan B.E., Cheng S. liu, 2006c. Operational parameters affecting the performance of Mediator less microbial fuel cell MFC, pp. 327-331.

Logan B.E., Bond, Lovely D. R., 2003. Biofuel cells recent advances and applications, Environ. Sci. Biotechnology, pp. 221-225.

Logan B.E , Ahn .Y. ,2009.Domestic wastewater treatment using microbial fuel cells and electrical energy production, Bioresources Technol, vol.101, pp.469-475.

Ramnarayan R., Logan B. E., Liu H., 2004. Production of electricity during wastewater treatment using a single chamber microbial fuel cell, Environ. Sci. and Technol.,vol. 38, pp.11-17.

\section{Biographical notes}

B. K. Pandey received M. Sc. From Dr. R. M. L. Avadh University Faizabab, India in 1996 and D. Phil. from H. N. B, Garhwal Central University Shrinagar India in 2006. He is a Assistant Professor in the Department of Applied Sciences, Madan Mohan Malaviya Engineering College, Gorakhpur, India. He has more than 10 years of experience in teaching and research. He has published more than ten research papers in referred international journals. He has also presented many research articles in different conferences. He has written two text books published by International Publisher (Cengage Learning). He is an active member of Indian Science Congress. His research interests include Solid State Physics and Electronics, Material Science, Renewable Sources of Energy and Applied Physics.

Vishwadeep Mishra is a student of B.Tech Final Year in the Department of Electrical Engineering at Madan Mohan Malaviya Engineering College,Gorakhpur ,U.P,India.He has presented various innovative technical designs at various science exhibitions and seminars such as All India Intel science expo. He has won various awards in technical programs like securing $2^{\text {nd }}$ position(SR) in 6th National Science Olympiad .His research area include studies on alternative techniques of energy generation and devising new methodologies for clean energy at minimal costs. He has developed MATLAB codes for Image processing and Fourier transform analysis. He is an active member of IEEE and SAE and has presented various review articles in national and local conferences.

Shweta Agrawal is a student of B.Tech Final year in the Department of Electrical Engineering at Madan Mohan Malaviyan Engineering College, Gorakhpur,U.P,India. She has given various review articles and presented research presentations on topics pertaining to Power System Engineering and Renewable Sources of Energy.She is an active member of IEEE .Her research areas include Power system Engineering ,Renewable Sources of Energy and clean energy systems.

Received February 2011

Accepted March 2011

Final acceptance in revised form June 2011 